\title{
ARTICLE
}

Received 20 Sep 2013 | Accepted 20 Feb 2014 | Published 24 Mar $2014 \quad$ DOI: 10.1038/ncomms4478

\section{A unified strategy for the synthesis of highly oxygenated diaryl ethers featured in ellagitannins}

Tsukasa Hirokane ${ }^{1}$, Yasuaki Hirata', Takayuki Ishimoto ${ }^{1}$, Kentaro Nishii ${ }^{1}$ \& Hidetoshi Yamada ${ }^{1}$

Ellagitannins are a family of polyphenols containing more than 1,000 natural products. Nearly $40 \%$ of these compounds contain a highly oxygenated diaryl ether that is one of the most critical elements to their structural diversity. Here, we report a unified strategy for the synthesis of highly oxygenated diaryl ethers featured in ellagitannins. The strategy involves oxa-Michael addition of phenols to an orthoquinone building block, with subsequent elimination and reductive aromatization. The design of the building block-a halogenated orthoquinone monoketal of gallal-reduces the usual instability of orthoquinone and controls addition/elimination. Reductive aromatization is achieved with perfect chemoselectivity in the presence of other reducible functional groups. This strategy enables the synthesis of different diaryl ethers. The first total synthesis of a natural ellagitannin bearing a diaryl ethers is performed to demonstrate that the strategy increases the number of synthetically available ellagitannins.

\footnotetext{
${ }^{1}$ School of Science and Technology, Kwansei Gakuin University, 2-1 Gakuen, Sanda 669-1337, Japan. Correspondence and requests for materials should be addressed to H.Y. (email: hidetosh@kwansei.ac.jp).
} 
T he structural diversity of natural products often derives from the oligomerization of monomers that are specific to each family of compounds. Snyder and co-workers have divided a large number of oligomeric natural products into two categories ${ }^{1}$ : serially and non-serially produced oligomers. In serially produced oligomers, monomers unite regiospecifically with definite bonding patterns; examples include DNA (Supplementary Note) and proteins. In contrast, in non-serially produced cases, oligomerization apparently unites monomers in a random manner, with no fixed position. This division can also be applied to polyphenols, although their structural diversity is sufficiently large to classify them into several structural families ${ }^{2}$.

Polyphenols have potential applications in medicine and health enhancement. However, their structure-activity/affinity relationships are not well understood due to the difficulty in obtaining a complete collection of systematically related analogues from nature. This difficulty might be resolved through chemical synthesis if all compounds of a polyphenol family could be synthesized. The methodologies required to achieve this exhaustive synthesis would differ from those used for a one-off total synthesis of a single compound. For the exhaustive synthesis of serially produced oligomers, the procurement of all component parts and the development of effective methods for assembling the parts are the most important tasks. For exhaustive synthesis of non-serially produced oligomers, the discovery of latent systems that exhibit structural diversity and the development of methodologies to address multipoint random oligomerizations are required. Attempts to satisfy these requirements for both serially and non-serially produced polyphenols have already begun, as evidenced by the work of Ohmori et al. ${ }^{3}$ and Snyder et al. $^{4}$, who have developed methods for synthesizing higher catechin oligomers and programmable resveratrol oligomers, respectively.

The family of ellagitannins, which consists of bioactivity- and structure-rich polyphenols ${ }^{5,6}$, has been found to contain more than 1,000 natural products to date ${ }^{7}$. The most basic ellagitannins consist of a glucose core with esterified galloyl and hexahydroxydiphenoyl (HHDP) groups (Fig. 1); however, the simple combination of these basic constituents is insufficient to generate structural diversity. Despite Snyder's classification of ellagitannins as serially produced oligomers ${ }^{1}$, the reality is not that simple. The HHDP groups on the glucose cores do not appear at fixed positions. Furthermore, disorders of the routine patterns in uniting the component parts frequently appear in higher ellagitannins. In addition, the family includes numerous component parts, including overoxidation ${ }^{8,9}$, modifications of the HHDP group ${ }^{10}$, conjugation with other natural constituents ${ }^{11-13}$ and production of the highly oxygenated diaryl ethers. Among these factors conferring structural diversity, the production of highly oxygenated diaryl ethers, $\mathrm{C}-\mathrm{O}$ digallates, is the most significant. $\mathrm{C}-\mathrm{O}$ digallates are structures that contain dimerized galloyl group(s) connected by a C-O bond, such as the dehydrodigalloyl (DHDG), tergalloyl and valoneoyl groups. These motifs allow oligomerization of basic ellagitannins, which expands diversity ${ }^{14}$. Nearly $40 \%$ of characterized natural ellagitannins contain $\mathrm{C}-\mathrm{O}$ digallates.

For the exhaustive synthesis of ellagitannins, one of the most fundamental tasks is the formation of the chiral HHDP group, a C-C digallate, which has been achieved through several procedures ${ }^{5-18}$. The second and most impactful task would be the establishment of a methodology for synthesizing $\mathrm{C}-\mathrm{O}$ digallates because their structure is the primary cause of structural diversity in this family. Therefore, establishment of this methodology should increase the number of synthetically available ellagitannins in an innovative manner. However, few reports of the synthesis of $\mathrm{C}-\mathrm{O}$ digallates have appeared in the literature. One of the rare examples is Feldman's synthesis of DHDG derivative 3 (Fig. 2a) ${ }^{19-21}$. This synthesis is a four-step sequence that starts from orthoquinone 4 through (1) the self-hetero Diels-Alder cycloaddition of $\mathbf{4}$ to produce a mixture of regioisomers $\mathbf{5 a}$ and $\mathbf{5 b}$, (2) $\beta$-elimination, as indicated by the curved arrows, (3) reduction of the orthoquinone, and (4) benzylation accompanying the Smiles rearrangement ${ }^{22}$, which converges the mixture into 3. Utilizing the DHDG derivative of $\mathbf{3}$,

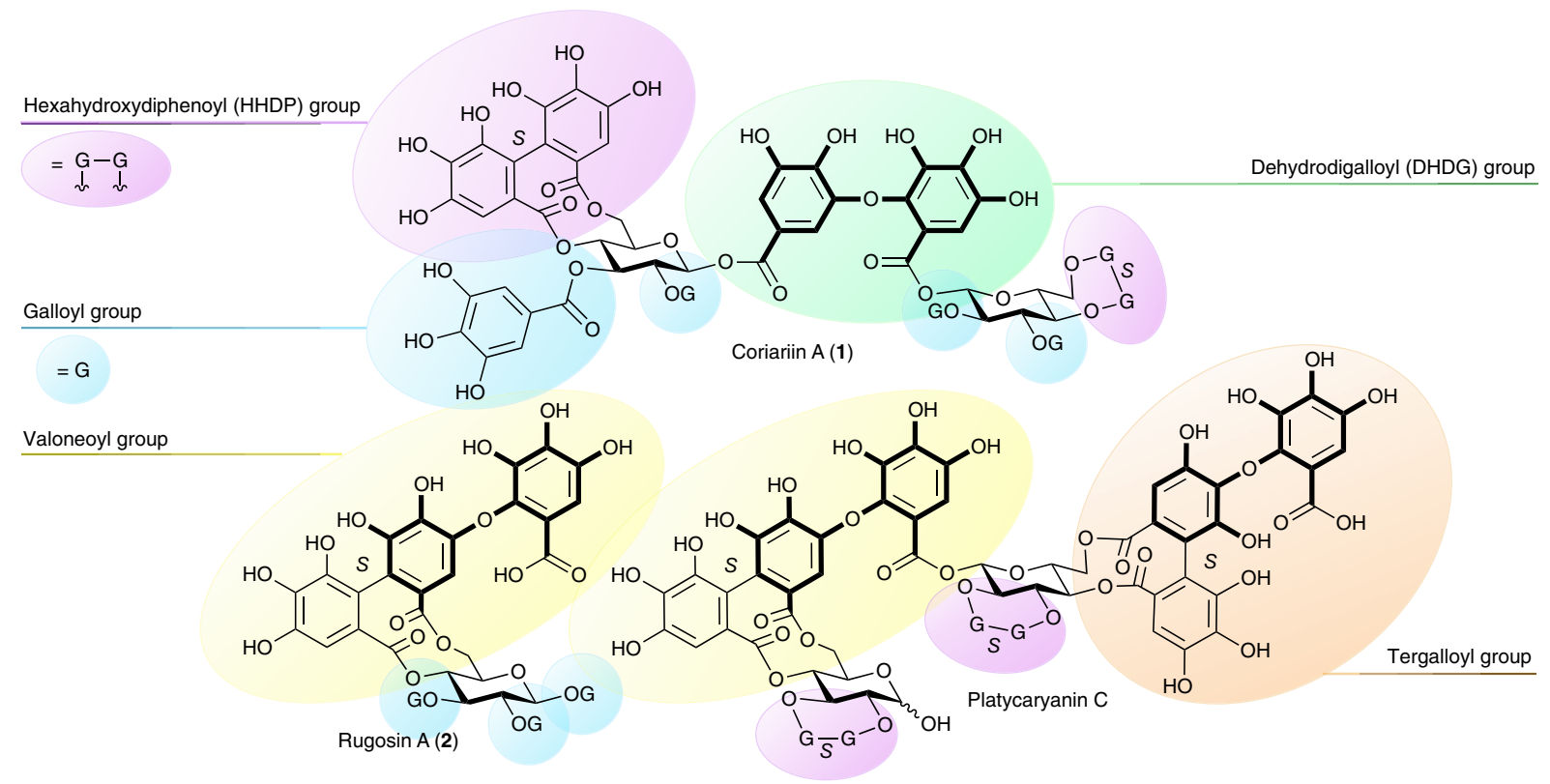

Figure 1 | Natural ellagitannins possessing highly oxygenated diaryl ethers. The parts indicated with bold lines are the highly oxygenated diaryl ethers, C-O digallates. Each common name is also indicated. The C-O digallates allow oligomerization of basic ellagitannins, which is a major factor in conferring structural diversity. However, the methods for synthesizing $\mathrm{C}-\mathrm{O}$ digallates have been quite limited to date. 
a

Previous work
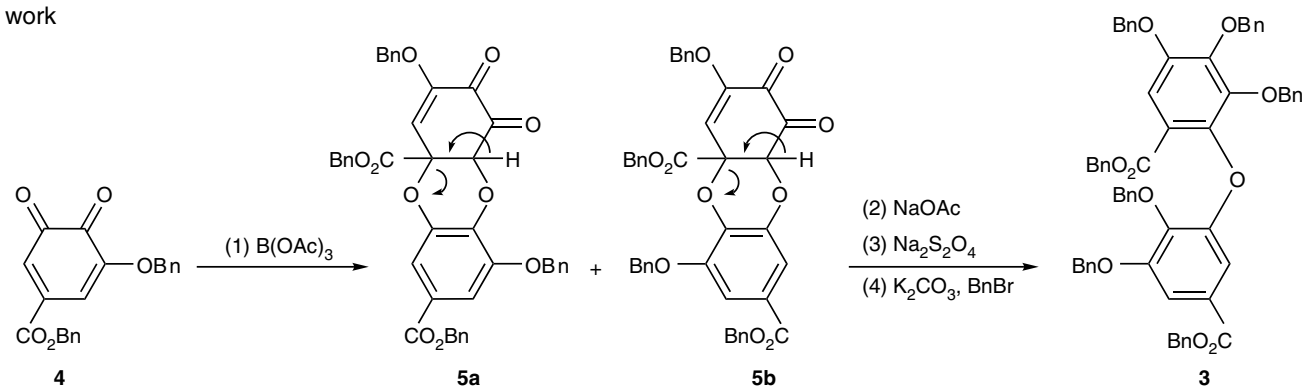

b

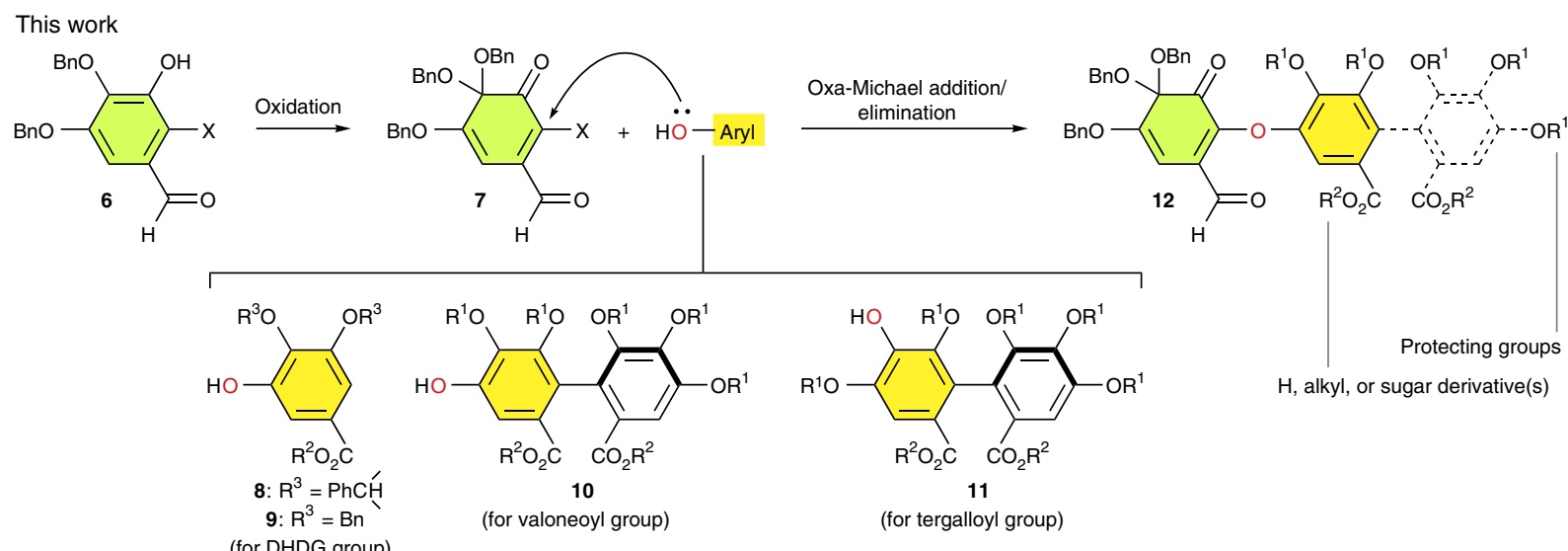

(for DHDG group)

(for valoneoyl group)

for tergalloyl group)

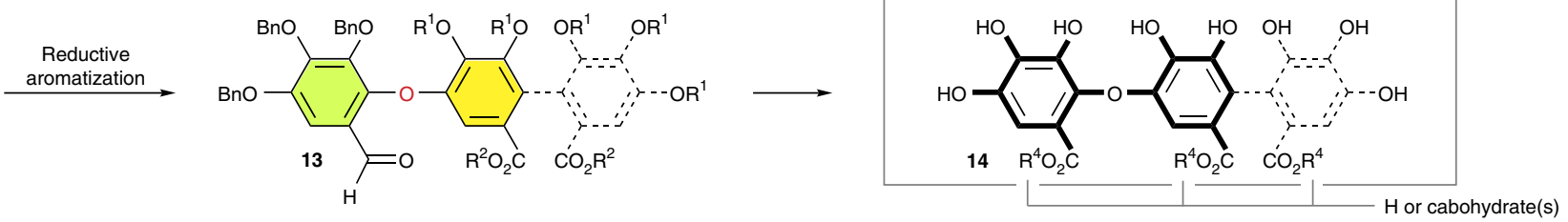

Figure 2 | Outlines of previous and present methods for the synthesis of C-O digallates. (a) Feldman's synthesis of the DHDG group, which was formerly the sole method for synthesizing a C-O digallate, the DHDG group, as applied to the total synthesis of ellagitannins. (b) The unified strategy of $\mathrm{C}-\mathrm{O}$ digallates (this work). Oxa-Michael addition of phenols 8-11 to key building block $\mathbf{7}$ and subsequent elimination formed the $\mathrm{C}-\mathrm{O}$ bond of the digallates. The design of building block $\mathbf{7}$ was critical. The monoketal and halogen $\mathrm{X}$ stabilized the structure. Halogen $\mathrm{X}$ made the oxa-Michael addition irreversible because leaving group $X$ caused smooth elimination after the oxa-Michael addition. In addition, $X$ limited the electrophilic position in oxaMichael addition to the $\beta$-carbon of the aldehyde but not to that of the ketone. The reductive aromatization of $\mathbf{1 2}$ required selective reduction of the orthoquinone monoketal in the presence of an aldehyde, an ester in the 'Aryl' part, and a benzylidene acetal when $\mathbf{8}$ was employed. The (S)-axial chiralities of $\mathbf{1 0}$ and $\mathbf{1 1}$ are drawn tentatively; thus, usage of the corresponding ( $R$ )-isomers and the racemates is also possible. Ac, acetyl; Bn, benzyl; Ph, phenyl.

they achieved the total synthesis of coriariin $\mathrm{A}(\mathbf{1})^{20}$, which is the sole ellagitannin containing the $\mathrm{C}-\mathrm{O}$ digallate synthesized to date. However, the application of this method to HHDP-containing $\mathrm{C}-\mathrm{O}$ digallates is quite difficult because the first step, the $\mathrm{C}-\mathrm{O}$ bond-forming reaction, relies on the self-dimerization of 4 .

Alternatively, Ullmann coupling can be used to prepare $\mathrm{C}-\mathrm{O}$ digallates. Nishioka and co-workers ${ }^{23}$ and Abe et al. ${ }^{24,25}$ independently synthesized $\mathrm{C}-\mathrm{O}$ digallates through Ullmann coupling as fully $\mathrm{O}$-methylated variants. However, total synthesis via fully O-methylated ellagitannins might be unproductive because complete cleavage of methyl ethers without degradation of the other part of the molecule has been difficult. Feldman et al. ${ }^{15}$ stated that per-O-methyl ethers are not likely to be ultimately useful in natural product synthesis. Actually, no route has resulted in unprotected ellagitannins through the methyl (Me)-protection of phenols ${ }^{25-28}$. Nonetheless, the Ullmann coupling of gallates protected by benzyl ethers, whose cleavage through hydrogenolysis is easy, is not very efficient at present ${ }^{29}$.

In this study, we developed an entirely novel and unified strategy for the synthesis C-O digallates, including the DHDG, tergalloyl and valoneoyl groups, which is a significant step toward the exhaustive synthesis of ellagitannins. To demonstrate the effectiveness of this strategy, we performed the first total synthesis of the valoneoyl-group-containing ellagitannin rugosin A (2).

\section{Results}

Strategy. Our strategy is outlined in Fig. 2b. The carboxylic acid moieties of $\mathrm{C}-\mathrm{O}$ digallate-containing motifs 14 are often unequally modified with or without carbohydrates or possess differently substituted carbohydrates. Therefore, the carboxylic acid moieties must be distinguished during synthesis. To achieve this distinction, we added an aldehyde group to key synthetic intermediate 13. The aryl-O-aryl bonds in the DHDG and valoneoyl groups are tri-ortho substituted, and their formation through cross-coupling catalysed by transition metals has been difficult ${ }^{30,31}$. Furthermore, the bond in the tergalloyl group is tetra-ortho substituted. For construction of multiortho-substituted aryl-O-aryl bonds, nucleophilic aromatic substitution $\left(S_{\mathrm{N}} \mathrm{Ar}\right)$ has been effective ${ }^{29,30}$. However, the 
reaction position of the galloyl group is electron rich, which is unfavourable to the $S_{N} A r$ reaction.

In this context, we planned to change the phenol to an electron-poor alkene through oxidative dearomatization. Thus, we constructed the sterically crowded aryl-O-aryl bond of 13 through oxa-Michael addition of a phenolic hydroxy group of $\mathbf{8}$ (ref. 32), 9 (ref. 33), 10 and $\mathbf{1 1}$ for the DHDG, valoneoyl, and tergalloyl groups to orthoquinone monoketal 7. Here, the design of building block 7, which contained a monoketal and a halogen atom $\mathrm{X}$, contributed to the success of this strategy. The corresponding orthoquinone without the monoketal dimerizes as 4 (ref. 29). When $\mathrm{X}=\mathrm{H}$, a phenolic nucleophile causes an undesired $\mathrm{C}-\mathrm{C}$ coupling ${ }^{29}$, presumably during competitive but reversible oxa-Michael addition. We expected the monoketal structure $^{34}$ and halogen $\mathrm{X}^{35-38}$ to protect against selfdimerizations in 7 . The $\mathrm{X}$ also might enhance the elimination that occurred following oxa-Michael addition to make the addition irreversible. Moreover, the electronegativity of the halogen would limit the electrophilic position of oxa-Michael addition to the $\beta$-carbon of the aldehyde but not to that of the ketone. Transposition of the monoketal and ketone of 7 might increase steric hindrance and obstruct the approach of phenols. The coupled 12 required the reductive aromatization of the orthoquinone monoketal to obtain 13. We achieved the selective reduction of the orthoquinone monoketal in the presence of an aldehyde, an ester in the 'Aryl' part, and a benzylidene acetal when 8 was used. Building block 7 resulted from oxidation of orthohalophenol 6.

Synthesis of the DHDG group. As building block 7, we prepared both bromide 7-Br and iodide 7-I (Fig. 3). The preparation began with the successive benzylation of $\mathbf{8}$ and concurrent reduction of the methyl ester and regioselective cleavage of one $\mathrm{C}-\mathrm{O}$ bond of the benzylidene group to give $\mathbf{1 5}$. The regioselectivity resulted from the coordination of the reductant on the less sterically hindered outside oxygen of the benzylidene acetal. The aliphatic alcohol in $\mathbf{1 5}$ was oxidized by molecular oxygen under Uemura's conditions $^{39}$ to yield aldehyde 16 (ref. 40). No 16 was obtained through oxidations using $\mathrm{MnO}_{2}$, 2,2,6,6-tetramethylpiperidine 1-oxyl (TEMPO) and $\mathrm{NaClO}$, TEMPO and (diacetoxyiodo) benzene, $\mathrm{COCl}_{2}$ and dimethyl sulfoxide (DMSO), Dess-Martin periodinane, $\mathrm{HBr}$ and $\mathrm{DMSO}^{41}$, or $\mathrm{HBr}$ and $\mathrm{H}_{2} \mathrm{O}_{2}$ (ref. 42). The bromination ${ }^{43,44}$ and iodination of 16 provided 17 and 18, respectively. Oxidation of phenols 17 and 18 with [bis(trifluoroacetoxy)iodo]benzene (PIFA) in the presence of
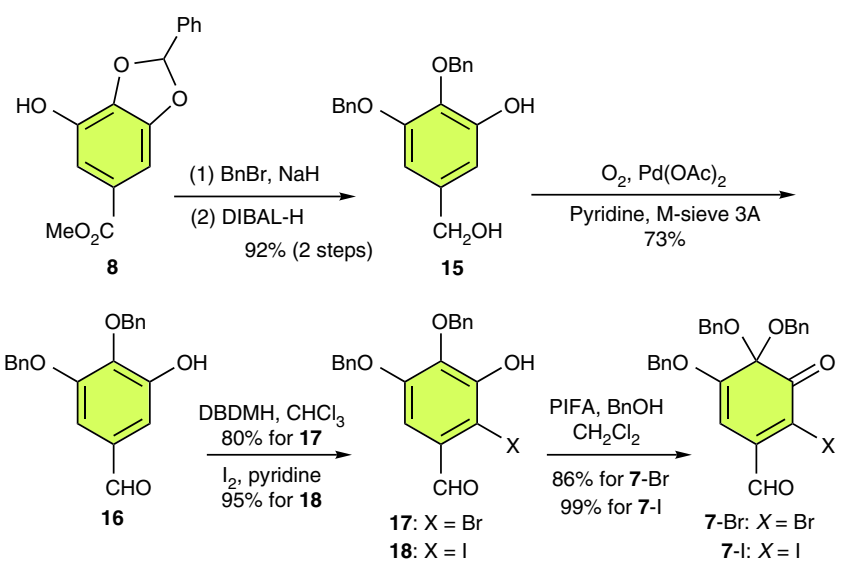

Figure 3 | Preparation of key building block 7. DBDMH, 1,3-dibromo-5,5dimethylhydantoin; DIBAL-H, diisobutylaluminium hydride; Me, methyl; M-sieve, molecular sieves; PIFA, [bis(trifluoroacetoxy)iodo]benzene. benzyl alcohol ${ }^{45,46}$ afforded orthoquinone monoketals 7-Br and -I, both of which were stable and did not dimerize at room temperature.

Using building blocks 7-Br and -I as electrophiles, we optimized the reaction conditions for oxa-Michael addition/ elimination (Fig. 4). Differently protected 8 and 9 were adopted as the nucleophiles. Among the four electrophile/nucleophile combinations, the reaction of $7-\mathrm{Br}$ with $\mathbf{8}$ was the fastest and gave the best yield. The reaction of 7 -I with 8 required a threefold longer reaction time $(1.5 \mathrm{~h})$ to finish and resulted in a slightly lower yield (89\%). Thus, reactivity was opposite the performance of the leaving groups. The best combination, $7-\mathrm{Br}$ and $\mathbf{8}$, consisted of the less sterically hindered electrophile and nucleophile; thus, the oxa-Michael addition might be the ratelimiting step of this sequence. The solvent effect was also remarkable. When the solvent $(\mathrm{MeCN})$ was changed to DMSO, $\mathrm{N}, \mathrm{N}$-dimethylformamide (DMF), pyridine, $\mathrm{EtOH}, \mathrm{CH}_{2} \mathrm{Cl}_{2}, \mathrm{THF}$, or toluene, 19 was obtained in $99,87,59,26,0,0$, or $0 \%$ NMR yields, respectively, thereby demonstrating that the use of $\mathrm{MeCN}$ or DMSO is optimal. Adoption of other bases such as $\mathrm{Na}_{2} \mathrm{CO}_{3}$, $\mathrm{Cs}_{2} \mathrm{CO}_{3}$ and $\mathrm{K}_{3} \mathrm{PO}_{4}$ resulted in a lower yield under every combination of electrophile and nucleophile.

We obtained the conditions for the chemoselective reduction of orthoquinone monoketal 19 (Fig. 4) by considering the ketal and adjacent alkene as an allyl ether. This allyl ether could form its Pd- $\pi$-allyl complex and be reduced selectively ${ }^{47-49}$. Thus,

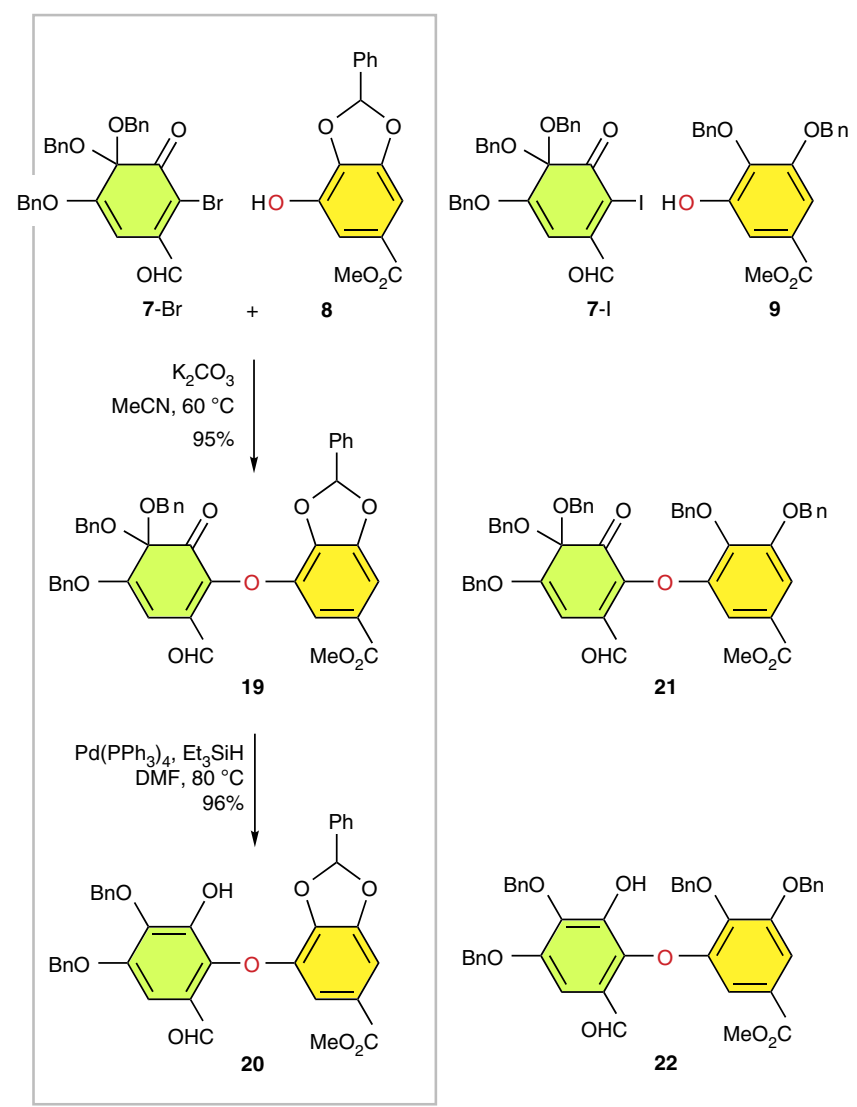

Figure 4 | Synthesis of the DHDG group. The first step is a subsequent oxa-Michael addition and elimination. Among all combinations with $\mathbf{7}-\mathrm{Br}$ and $\mathbf{7}-\mathrm{I}$ as the electrophiles and $\mathbf{8}$ and $\mathbf{9}$ as the nucleophiles, the combination of $\mathbf{7 - B r}$ and $\mathbf{8}$ was the optimal one. The second step is a chemoselective reduction of the orthoquinone monoketal in the presence of the other reducible functional groups. The ketal and adjacent alkene acted as an allyl ether to form a Pd- $\pi$-allyl complex, which conferred chemoselectivity. DMF $=\mathrm{N}, \mathrm{N}$-dimethylformamide; Et, ethyl. 
a

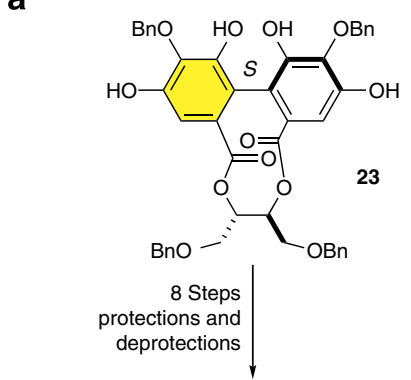

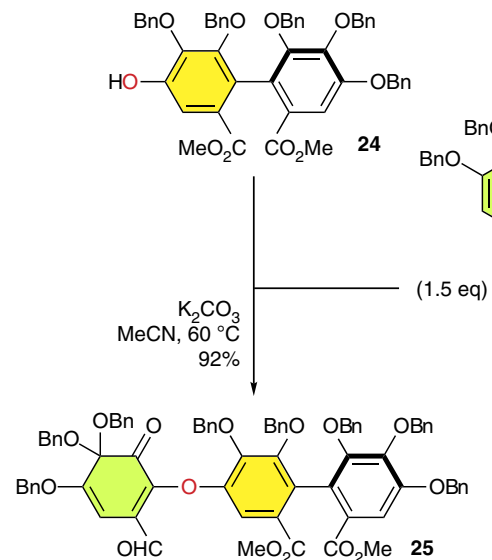

b<smiles>O=C(OCCCOC(=O)c1cc(O)c(OCc2ccccc2)c(O)c1)c1cc(O)c(O)c(O)c1</smiles>

1) $\mathrm{CuCl}_{2},{ }^{n} \mathrm{BuNH}_{2}, \mathrm{MeOH}, 93 \%$ for 29 2) $\mathrm{MOMCl},{ }^{i} \mathrm{Pr}_{2} \mathrm{NEt}, 85 \%$ for 30 3) $\mathrm{DDQ}, 88 \%$<smiles>COc1cc(C(=O)OCCCO)c(-c2c(C(=O)OCc3ccccc3)cc(OC)c(OCc3ccccc3)c2OC)c(OC)c1OC</smiles>

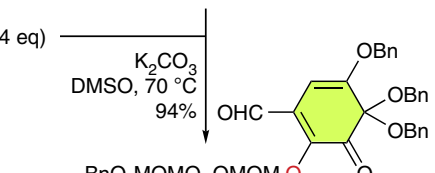<smiles>COC(=O)c1cc(OC)c(OC)c(OC)c1-c1c(OC)cc(OC)c(OC)c1OC</smiles>
$\mathrm{Et}_{3} \mathrm{SiH}, \mathrm{Pd}\left(\mathrm{PPh}_{3}\right)_{4}$
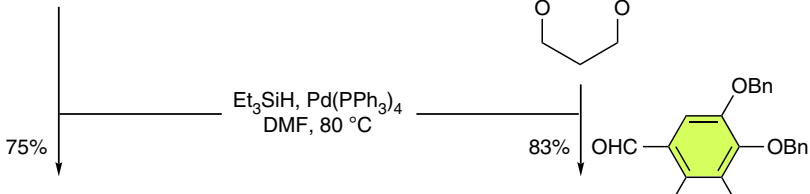<smiles>COC(=O)c1cc(OCc2ccccc2)c(OCc2ccccc2)c(C(=O)OCc2ccccc2)c1-c1c(C(C)=O)cc(Oc2c(C)cc(OCc3ccccc3)c(OCc3ccccc3)c2O)c(OCc2ccccc2)c1OCc1ccccc1</smiles><smiles>C[13CH3]</smiles><smiles>COc1cc(OC)c(Oc2cc(OC)c(-c3c(OC)c(OC)cc(OC)c3OC)c(OC)c2OC)c(OC)c1OC</smiles><smiles>COc1cc(C(=O)OCCCOC(=O)c2cc(OC)c(OC)c(OC)c2-c2c(OC)c(OC)cc(C(=O)OCCO)c2OC)c(OC)c(OC)c1OC</smiles>

Figure 5 | Syntheses of the valoneoyl (a) and tergalloyl (b) groups. The sequence developed for the synthesis of the DHDG group-that is, oxa-Michael addition to $\mathbf{7}-\mathrm{Br}$, elimination and reductive aromatization-was applied to the synthesis of the valoneoyl and tergalloyl groups. These successful syntheses showed that the sequence was a unified method for the synthesis of C-O digallates. The intramolecular coupling of $\mathbf{2 8}$ is the first HHDP synthesis starting from unequally protected gallates. For structures of $\mathbf{2 9}$ and $\mathbf{3 0}$, see Supplementary Methods 35 and 36 . Bu, butyl; DDQ, 2,3-dichloro-5,6-dicyano-p-benzoquinone; Nap, 2-naphthylmethyl; Pr, propyl.

treatment of 19 with catalytic $\mathrm{Pd}\left(\mathrm{PPh}_{3}\right)_{4}$ in the presence of $\mathrm{Et}_{3} \mathrm{SiH}$ in DMF gave 20 in 96\% yield and demonstrated the development of a new synthetic method for the DHDG group. The solvent was selected after evaluation of $\mathrm{MeCN}, \mathrm{CH}_{2} \mathrm{Cl}_{2}$, DMF, EtOH, THF and toluene. The optimal conditions were also applicable to 21, yielding 22 in $95 \%$ yield. The results provided by other typical reductions were as follows. $\mathrm{NaBH}_{4}$ reduced the aldehyde of 19 and thus did not provide the desired 20, although simple orthoquinone monoketals are reduced by $\mathrm{NaBH}_{4}$ (refs 50 , 51). The use of $\mathrm{Et}_{3} \mathrm{SiH}$ in the presence of TFA, which was a reduction condition of acetals ${ }^{52}$, produced a complex mixture.
A radical reduction induced by ${ }^{n} \mathrm{Bu}_{3} \mathrm{SnH}$ and AIBN afforded 20 with a $51 \%$ yield, although such a radical reduction is uncommon for orthoquinone monoketals.

Synthesis of the valoneoyl and tergalloyl groups. We expanded the developed method to the valoneoyl and tergalloyl groups (Fig. 5). For this purpose, phenols $\mathbf{2 4}$ and $\mathbf{3 1}$ were the nucleophiles to 7-Br. Phenol 24 was prepared from known (S)-HHDP compound 23 (ref. 53) via an eight-step protection/deprotection process (Supplementary Methods 11-19). For the preparation of 


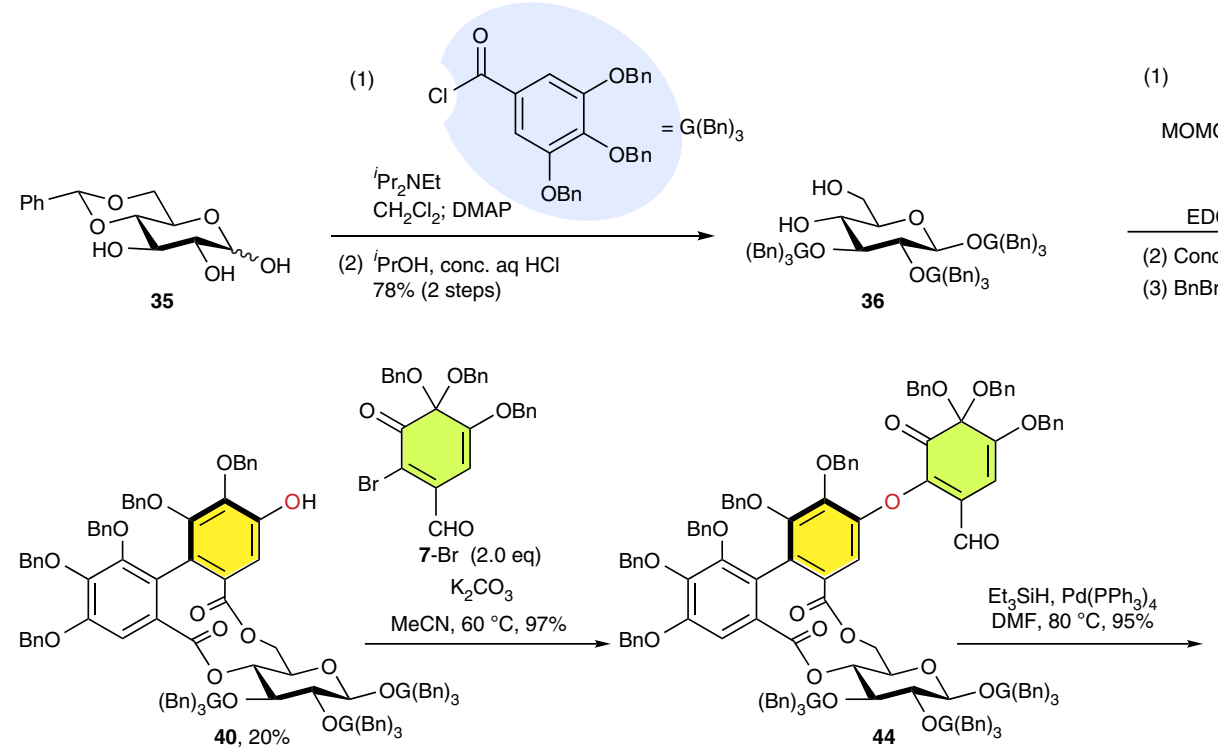

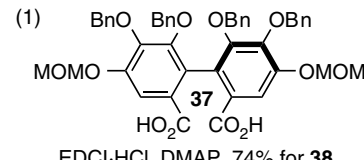

(2) Conc. aq HCl, ${ }^{i} \mathrm{PrOH}, 92 \%$ for 39 (3) $\mathrm{BnBr}, \mathrm{K}_{2} \mathrm{CO}_{3}$

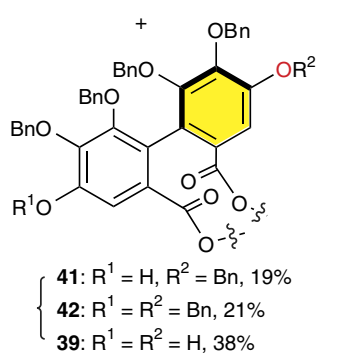

MOMCl,

${ }^{\mathrm{i}} \mathrm{Pr}_{2} \mathrm{NEt}, 97 \%$

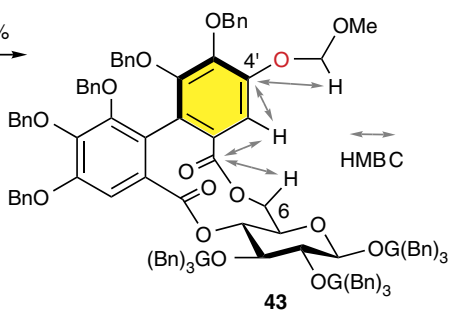

(1) $\mathrm{BnBr}, \mathrm{K}_{2} \mathrm{CO}_{3}, \mathrm{MeCN}, 86 \%$ for 46 (2) $\mathrm{NaClO}_{2}, \mathrm{NaH}_{2} \mathrm{PO}_{4}, \mathrm{Me}_{2} \mathrm{C}=\mathrm{CHMe}, 77 \%$ for 47

(3) $\mathrm{H}_{2}, \mathrm{Pd} / \mathrm{C}, 97 \%$

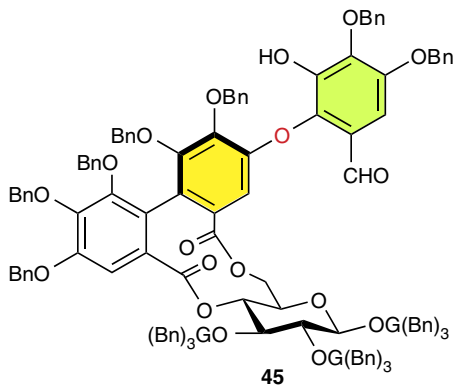

45

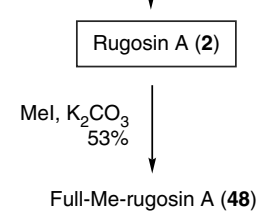

Figure 6 | Total synthesis of rugosin A (2). The unified method for the synthesis of C-O digallates was applied to the total synthesis of a natural ellagitannin. This example is the first total synthesis of a valoneoyl group containing ellagitannin. For structures of 38, 39, 46 and 47, see Supplementary Methods 46, 47, 53 and 54, respectively. aq, aqueous; conc., concentrated; DMAP, 4-(dimethylamino)pyridine; EDCl, N-(3-dimethylaminopropyl)- $\mathrm{N}^{\prime}$ ethylcarbodiimide; $\mathrm{G}(\mathrm{Bn})_{3}$, tri-O-benzylgalloyl; $\mathrm{HMBC}$, heteronuclear multiple-bond correlation.

31, we developed C-C coupling of unequally protected gallates to avoid long protection/deprotection steps, similar to the preparation of 24. Specifically, the intramolecular coupling of $\mathbf{2 8}$ (Supplementary Methods 27-34), where the middle hydroxyl group of each galloyl group was protected by benzyl and 2-naphthylmethyl groups, was mediated by $\mathrm{CuCl}_{2}-{ }^{n} \mathrm{BuNH}_{2}$ (ref 18) and afforded the corresponding coupled product 29 with an excellent yield. The subsequent methoxymethyl (MOM) protections for $\mathbf{3 0}$ and removal of the 2-naphthylmethyl group $^{54}$ gave 31 . The oxa-Michael addition/elimination of $\mathbf{2 4}$ and 31 with the building block $7-\mathrm{Br}$ furnished 25 and 32, respectively.

To obtain excellent yields, the use of 1.5 and 4 equivalents of $7-\mathrm{Br}$ was required. Although $7-\mathrm{Br}$ was confirmed to be stable at 60 and $70^{\circ} \mathrm{C}$ in $\mathrm{MeCN}$ and DMSO, respectively, for at least $10 \mathrm{~h}$, the addition of $\mathrm{K}_{2} \mathrm{CO}_{3}$ to each solution degraded 7-Br. The degradation was faster in DMSO than in MeCN. Thus, in the degradation experiments, $7-\mathrm{Br}$ disappeared within $30 \mathrm{~min}$ at $70{ }^{\circ} \mathrm{C}$ in DMSO but $12 \%$ of $7-\mathrm{Br}$ was recovered after the reaction mixture was heated for $2 \mathrm{~h}$ in $\mathrm{MeCN}$. However, when $\mathrm{MeCN}$ was used as the reaction solvent in the synthesis of 32 , the reaction rate decreased substantially. In the reactions that provided 25 and 32, competition between the degradation of $7-\mathrm{Br}$ and the desired transformation required excess amounts of $7-\mathrm{Br}$. The more obvious competition with $\mathbf{3 1}$ was due to increased steric hindrance around the nucleophilic oxygen atom. The chemoselective reduction of $\mathbf{2 5}$ and $\mathbf{3 2}$ provided $\mathbf{2 6}$ and 33, respectively, whose structures contained the skeletons of valoneoyl and tergalloyl groups. These syntheses demonstrate the unified applicability of the method for the synthesis of C-O digallates. We confirmed the structures of $\mathbf{2 6}$ and $\mathbf{3 3}$ by transforming them to known compounds 27 (refs 25, 55) (Supplementary Tables 1 and 2 and Supplementary Methods 22-26) and 34 (ref. 56) (Supplementary Table 3 and Supplementary Methods 40-43), respectively.

Total synthesis of rugosin A. The unified method paved the way for the total synthesis of rugosin A (2, Fig. 1), an ellagitannin bearing a valoneoyl group. This ellagitannin was isolated from Rosa rugosa THUNB and characterized by Okuda et al..$^{57}$ The synthesis commenced with the preparation of 1,2,3-tri-Ogalloylated $\beta$-D-glucose 36 (Fig. 6). We prepared 36 from 4,6-Obenzylidene-D-glucose $(35)^{58}$ through galloylation of the triol followed by removal of the benzylidene group. Successive transformations-specifically, the double esterification ${ }^{59}$ of 36 with 37 to provide the 4,6-(S)-HHDP bridged 38, removal of the MOM groups for diol 39 and partial benzylation of free phenolic hydroxyl groups-yielded monohydroxy compound $\mathbf{4 0}$ along with its regioisomer 41, a fully benzylated compound 42 (ref. 60), and recovered diol 39. Separation of these four compounds was possible by silica-gel column chromatography eluted with a mixture of $n$-hexane, toluene and ethyl acetate (EtOAc). We determined the position of the hydroxyl group in $\mathbf{4 0}$ as its MOM-protected form $\mathbf{4 3}$ by tracing heteronuclear multiple-bond correlation observed in THF- $d_{8}$, as illustrated in Figure 6. Each observation in acetone- $d_{6}, \mathrm{CDCl}_{3}$ and $\mathrm{CD}_{3} \mathrm{CN}$ gave inconclusive spectra due to overlapping of the critical peaks. The oxa-Michael 


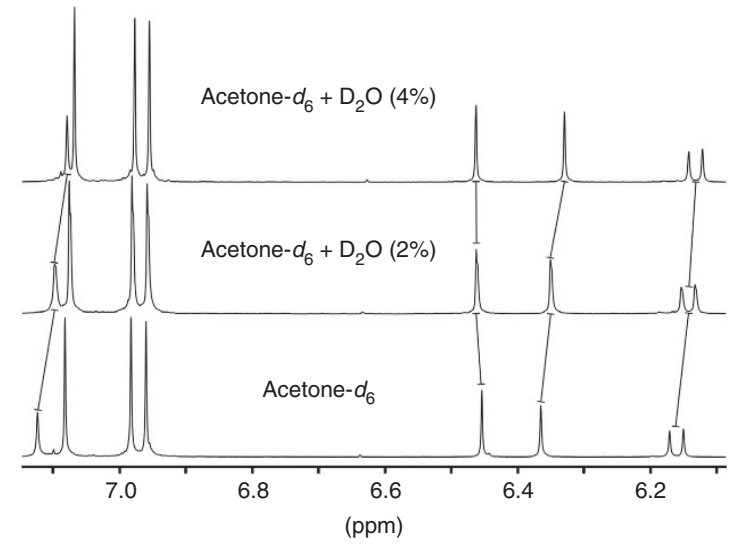

Figure 7 | Variable ${ }^{\mathbf{1}} \mathbf{H}$ NMR chemical shift of $\mathbf{2}$. The chemical shifts in the ${ }^{1} \mathrm{H}$ NMR spectra changed after the addition of $\mathrm{D}_{2} \mathrm{O}$ to a solution of $\mathbf{2}$ in acetone- $d_{6}$. This behaviour did not allow the complete identification of synthesized $\mathbf{2}$ by comparison with the ${ }^{1} \mathrm{H}$ NMR spectrum of natural $\mathbf{2}$. Therefore, we prepared the permethylated analogue $\mathbf{4 8}$ (Fig. 6) for identification.

addition/elimination with $\mathbf{4 0}$ and $7-\mathrm{Br}$ furnished the corresponding C-O-bonded orthoquinone monoketal 44. Reduction of the orthoquinone monoketal produced 45, which formed the skeleton of 2 . Finally, successive benzylation of the hydroxyl group of $\mathbf{4 5}$ to provide $\mathbf{4 6}$, sodium chlorite-mediated oxidation $^{61-63}$ of the aldehyde to the corresponding carboxylic acid 47, and complete debenzylation afforded 2 . The ${ }^{1} \mathrm{H}$ and ${ }^{13} \mathrm{C}$ NMR spectra of $\mathbf{2}$ were in agreement with those of the natural product; however, subtle differences in chemical shifts were observed (Supplementary Tables 4 and 5). The identification of unprotected ellagitannins via NMR data is occasionally difficult because chemical shifts are prone to change due to the conditions of the observation. For example, the addition of $\mathrm{D}_{2} \mathrm{O}$ changed the proton nuclear magnetic resonance $\left({ }^{1} \mathrm{H}\right.$ NMR) chemical shifts of 2 (Fig. 7). Therefore, we identified the product after full methylation of synthesized 2 ; the ${ }^{1} \mathrm{H}$ NMR spectrum of fully methylated 48 was identical to that previously reported ${ }^{57}$ (Supplementary Table 6).

\section{Discussion}

The creation of building block 7-Br made possible a unified synthetic approach to $\mathrm{C}-\mathrm{O}$ digallates with DHDG, valoneoyl and tergalloyl groups. This method features the oxa-Michael addition of a phenolic nucleophile to $7-\mathrm{Br}$, subsequent elimination and reduction of the orthoquinone monoketal. In addition, we report the following three new achievements: (1) the syntheses of the valoneoyl and tergalloyl groups into a form that could be applicable for the total synthesis of unprotected ellagitannins, (2) the improvement in the method of synthesizing the HHDP group through intramolecular aryl-aryl coupling between unequally protected gallates, and (3) the total synthesis of the valoneoylgroup-containing ellagitannin. Because $\mathrm{C}-\mathrm{O}$ digallates have frequently appeared in natural ellagitannins as key constituents to induce structural diversity, this work increases the number of synthetically available ellagitannins in an innovative manner.

\footnotetext{
Methods

General. Reactions were performed under an $\mathrm{N}_{2}$ or Ar atmosphere unless otherwise noted. The phrase 'the general drying procedure' indicates successive treatments consisting of $\mathrm{MgSO}_{4}$-drying of an organic layer after extraction, removal of $\mathrm{MgSO}_{4}$ by filtration and concentration of the filtrate. For detailed general methods, compound characterization data, and ${ }^{1} \mathrm{H}$ and ${ }^{13} \mathrm{C}$ NMR spectra of the compounds prepared in this study, see Supplementary Method 1, 2-54 and Supplementary Figs $1-51$, respectively.
}

Synthesis of compound 15. A mixture of 8 (ref. 32) (1.00 g, $3.67 \mathrm{mmol}$ ), $\mathrm{NaH}$ $(60 \%$ in mineral oil $220 \mathrm{mg}, 132 \mathrm{mg}$ as $\mathrm{NaH}, 5.51 \mathrm{mmol})$ and $\mathrm{BnBr}(942 \mathrm{mg}$, $5.51 \mathrm{mmol})$ in DMF and toluene $(\mathrm{v} / \mathrm{v}=3 / 1,37 \mathrm{ml})$ was stirred for $2 \mathrm{~h}$ at room temperature (RT). After the addition of satd aq $\mathrm{NH}_{4} \mathrm{Cl}(20 \mathrm{ml})$, the aq mixture was extracted with $\mathrm{Et}_{2} \mathrm{O}$. The organic layer was successively washed with $\mathrm{H}_{2} \mathrm{O}$ and brine. After the general drying procedure, the resulting residue was purified by column chromatography (CC) $\left(30 \mathrm{~g}\right.$ of $\mathrm{SiO}_{2}, n$-hexane/EtOAc $=20 / 1$ to $\left.5 / 1\right)$ to afford the corresponding benzyl ether (1.22 g, 92\% yield) as a white solid.

Diisobutylaluminium hydride ( $1.0 \mathrm{M}$ in THF, $9.7 \mathrm{ml}, 9.7 \mathrm{mmol}$ ) was added to a solution of the benzyl ether $(1.00 \mathrm{~g}, 2.78 \mathrm{mmol})$ in $\mathrm{CH}_{2} \mathrm{Cl}_{2}(10 \mathrm{ml})$. The solution was stirred for $1 \mathrm{~h}$ at $0{ }^{\circ} \mathrm{C}$. After the addition of $1 \mathrm{M}$ hydrochloric acid $(20 \mathrm{ml})$, the aq mixture was extracted with EtOAc. The organic layer was successively washed with $1 \mathrm{M}$ hydrochloric acid, $\mathrm{H}_{2} \mathrm{O}$ and brine. After the general drying procedure, the resulting residue was purified by $\mathrm{CC}\left(20 \mathrm{~g}\right.$ of $\mathrm{SiO}_{2}, n$-hexane/EtOAc $=5 / 1$ to $\left.1 / 1\right)$ to afford 15 (935 mg, 100\% yield) as a colourless syrup.

Synthesis of compound 16. A mixture of $15(220 \mathrm{mg}, 654 \mu \mathrm{mol})$, pyridine $(51.7 \mathrm{mg}, 654 \mu \mathrm{mol})$, activated $3 \mathrm{~A}$ molecular sieves $(300 \mathrm{mg})$ and $\mathrm{Pd}(\mathrm{OAc})_{2}$ $(14.7 \mathrm{mg}, 65.4 \mu \mathrm{mol})$ in $\mathrm{DMF}(6.5 \mathrm{ml})$ was stirred for $18 \mathrm{~h}$ at $90^{\circ} \mathrm{C}$ under an $\mathrm{O}_{2}$ atmosphere. After the addition of $\mathrm{Et}_{2} \mathrm{O}(5 \mathrm{ml})$ and $1 \mathrm{M}$ hydrochloric acid $(15 \mathrm{ml})$, the aq mixture was extracted with $\mathrm{Et}_{2} \mathrm{O}$. The organic layer was washed with satd aq $\mathrm{NaHCO}_{3}$. After the general drying procedure, the resulting residue was purified by $\mathrm{CC}\left(7.0 \mathrm{~g}\right.$ of $\mathrm{SiO}_{2}, n$-hexane/EtOAc $=15 / 1$ to $\left.4 / 1\right)$ to afford $16(159 \mathrm{mg}, 73 \%$ yield $)$ as a white solid. ${ }^{1} \mathrm{H}$ NMR data for $\mathbf{1 6}$ were identical to those previously reported ${ }^{40}$.

Synthesis of compound 17. A mixture of 1,3-dibromo-5,5-dimethylhydantoin $(428 \mathrm{mg}, 1.50 \mathrm{mmol})$ and $16(1.00 \mathrm{~g}, 2.99 \mathrm{mmol})$ in $\mathrm{CHCl}_{3}(30 \mathrm{ml})$ was stirred for $24 \mathrm{~h}$ at RT. After the addition of $10 \%$ aq $\mathrm{Na}_{2} \mathrm{~S}_{2} \mathrm{O}_{3}$, the aq mixture was extracted with $\mathrm{Et}_{2} \mathrm{O}$. The organic layer was washed with $\mathrm{H}_{2} \mathrm{O}$. After the general drying procedure, the crude product was purified by crystallization (EtOAc/n-hexane) to afford 17 (994 mg, 80\% yield) as a white solid.

Synthesis of compound 18. A mixture of $16(50.0 \mathrm{mg}, 150 \mu \mathrm{mol})$, pyridine $(29.1 \mathrm{mg}, 369 \mu \mathrm{mol})$ and $\mathrm{I}_{2}(45.5 \mathrm{mg}, 179 \mu \mathrm{mol})$ in $\mathrm{CHCl}_{3}(1.5 \mathrm{ml})$ was stirred for $4 \mathrm{~h}$ at RT. Further $\mathrm{I}_{2}(23.9 \mathrm{mg}, 94.2 \mu \mathrm{mol})$ was added, and the mixture was stirred for an additional $20 \mathrm{~h}$. After $10 \%$ aq $\mathrm{Na}_{2} \mathrm{~S}_{2} \mathrm{O}_{3}$ was added until the mixture became colourless $(5 \mathrm{ml})$, the aq mixture was extracted with $\mathrm{Et}_{2} \mathrm{O}$. The organic layer was successively washed with $\mathrm{H}_{2} \mathrm{O}, 1 \mathrm{M}$ hydrochloric acid and brine. After the general drying procedure, the resulting residue was purified by CC ( $3 \mathrm{~g}$ of $\mathrm{SiO}_{2}, n$-hexane/ EtOAc $=15 / 1$ to $7 / 1)$ to afford $\mathbf{1 8}(65.6 \mathrm{mg}, 95 \%$ yield $)$ as a white solid.

Synthesis of compound 7-Br. PIFA (563 mg, $1.31 \mathrm{mmol}$ ) was added to a solution of $17(360 \mathrm{mg}, 872 \mu \mathrm{mol})$ in $\mathrm{CH}_{2} \mathrm{Cl}_{2}(2.0 \mathrm{ml})$ and $\mathrm{BnOH}(3.0 \mathrm{ml})$. The solution was stirred for $5 \mathrm{~min}$ at RT. After the addition of $\mathrm{Et}_{2} \mathrm{O}(30 \mathrm{ml})$ and satd aq $\mathrm{NaHCO}_{3}$ $(10 \mathrm{ml})$, the aq mixture was extracted with $\mathrm{Et}_{2} \mathrm{O}$. The organic layer was successively washed with $\mathrm{H}_{2} \mathrm{O}$. After the general drying procedure, the resulting residue was purified by CC $\left(90 \mathrm{~g}\right.$ of $\mathrm{SiO}_{2}, n$-hexane/toluene $=1 / 0$ to $1 / 2$ to $\left.1 / 3\right)$ to afford $7-\mathrm{Br}$ (390 $\mathrm{mg}, 86 \%$ yield) as a red syrup.

Synthesis of compound 7-I. A mixture of $18(300 \mathrm{mg}, 652 \mu \mathrm{mol})$ and PIFA (336 mg, $782 \mu \mathrm{mol})$ in $\mathrm{CH}_{2} \mathrm{Cl}_{2}(1.0 \mathrm{ml})$ and $\mathrm{BnOH}(5.0 \mathrm{ml})$ was stirred for $5 \mathrm{~min}$ at RT. After the addition of $\mathrm{Et}_{2} \mathrm{O}(20 \mathrm{ml})$ and satd aq $\mathrm{NaHCO}_{3}(10 \mathrm{ml})$, the aq mixture was extracted with $\mathrm{Et}_{2} \mathrm{O}$. The organic layer was washed with $\mathrm{H}_{2} \mathrm{O}$. After the general drying procedure, the resulting residue was purified by CC ( $9.0 \mathrm{~g}$ of $\mathrm{SiO}_{2}, n$-hexane/EtOAc $=50 / 1$ to $\left.15 / 1\right)$ to afford 7 -I $(366 \mathrm{mg}, 99 \%$ yield $)$ as a red syrup.

Reaction of 7-Br with 8. A mixture of 7- $\mathrm{Br}(53.4 \mathrm{mg}, 103 \mu \mathrm{mol}), \mathbf{8}(36.5 \mathrm{mg}$, $134 \mu \mathrm{mol})$ and $\mathrm{K}_{2} \mathrm{CO}_{3}(71.2 \mathrm{mg}, 515 \mu \mathrm{mol})$ in $\mathrm{MeCN}(1.4 \mathrm{ml})$ was stirred for $30 \mathrm{~min}$ at $60^{\circ} \mathrm{C}$. After the mixture was cooled to RT, $\mathrm{Et}_{2} \mathrm{O}(5 \mathrm{ml})$ and $1 \mathrm{M}$ hydrochloric acid $(5 \mathrm{ml})$ were added. The aq mixture was extracted with $\mathrm{Et}_{2} \mathrm{O}$. The organic layer was successively washed with satd aq $\mathrm{NaHCO}_{3}$ and brine. After the general drying procedure, the crude product was purified by $\mathrm{CC}\left(2.0 \mathrm{~g}\right.$ of $\mathrm{SiO}_{2}$, $n$-hexane/EtOAc $=20 / 1$ to $10 / 1)$ to afford $19(69.3 \mathrm{mg}, 95 \%$ yield $)$ as a red syrup.

Reaction of 7-I with 8. In a reaction similar to that described in the previous procedure, the use of 7-I $(43.0 \mathrm{mg}, 75.9 \mu \mathrm{mol}), 8(26.9 \mathrm{mg}, 98.7 \mu \mathrm{mol})$ and $\mathrm{K}_{2} \mathrm{CO}_{3}$ $(40.9 \mathrm{mg}, 296 \mu \mathrm{mol})$ provided a crude product containing 19. The reaction time was $1.5 \mathrm{~h}$. The crude product was purified by $\mathrm{CC}\left(2.0 \mathrm{~g}\right.$ of $\mathrm{SiO}_{2}, n$-hexane/ EtOAc $=20 / 1$ to $6 / 1)$ to afford $19(48.1 \mathrm{mg}, 89 \%$ yield $)$.

Reaction of 7-Br with 9. In a reaction similar to that described for $\mathbf{7 - B r}$ and $\mathbf{8}$, the use of $7-\mathrm{Br}(20.3 \mathrm{mg}, 39.1 \mu \mathrm{mol}), 9(18.9 \mathrm{mg}, 50.8 \mu \mathrm{mol})$ and $\mathrm{K}_{2} \mathrm{CO}_{3}(27.0 \mathrm{mg}$, $195 \mu \mathrm{mol})$ provided $21(18.9 \mathrm{mg}, 60 \%$ yield) as a red syrup. The reaction time was $50 \mathrm{~min}$. 
Reaction of 7-I with 9. In a reaction similar to that described for 7-Br and 8, the use of 7-I ( $10.0 \mathrm{mg}, 17.7 \mu \mathrm{mol}), 9(8.4 \mathrm{mg}, 22.9 \mu \mathrm{mol}), \mathrm{K}_{2} \mathrm{CO}_{3}(12.3 \mathrm{mg}, 89.3 \mu \mathrm{mol})$ and $\mathrm{MeCN}$ (1.0 ml) provided a crude product containing $\mathbf{2 1}$. The yield of $\mathbf{2 1}$ was $46 \%$ on the basis of the ${ }^{1} \mathrm{H}$ NMR spectra of the crude product.

Synthesis of compound 20. $\mathrm{Pd}\left(\mathrm{PPh}_{3}\right)_{4}(4.8 \mathrm{mg}, 4.2 \mu \mathrm{mol})$ was added to a solution of $19(59.6 \mathrm{mg}, 83.9 \mu \mathrm{mol})$ and $\mathrm{Et}_{3} \mathrm{SiH}(19.5 \mathrm{mg}, 168 \mu \mathrm{mol})$ in DMF $(1.0 \mathrm{ml})$. The solution was stirred for $15 \mathrm{~min}$ at $80^{\circ} \mathrm{C}$. After the mixture cooled to RT, $\mathrm{Et}_{2} \mathrm{O}$ $(5 \mathrm{ml})$ and $1 \mathrm{M}$ hydrochloric acid $(5 \mathrm{ml})$ were added. The aq mixture was extracted with $\mathrm{Et}_{2} \mathrm{O}$. The organic layer was successively washed with satd aq $\mathrm{NaHCO}_{3}$ and brine. After the general drying procedure, the crude product was purified by CC $\left(1.0 \mathrm{~g}\right.$ of $\mathrm{SiO}_{2}, n$-hexane/EtOAc $=20 / 1$ to $\left.5 / 1\right)$ to afford $20(48.8 \mathrm{mg}, 96 \%)$ as a pale yellow syrup.

Synthesis of compound 22. In a reaction similar to that described for the synthesis of 20, the use of $21(52.0 \mathrm{mg}, 64.8 \mu \mathrm{mol}), \mathrm{Et}_{3} \mathrm{SiH}(15.1 \mathrm{mg}, 130 \mu \mathrm{mol})$ and $\mathrm{Pd}\left(\mathrm{PPh}_{3}\right)_{4}(0.7 \mathrm{mg}, 0.6 \mu \mathrm{mol})$ provided $22(42.8 \mathrm{mg}, 95 \%$ yield $)$ as a colourless syrup after purification by CC $\left(1.0 \mathrm{~g}\right.$ of $\mathrm{SiO}_{2}, n$-hexane/EtOAc $=10 / 1$ to $\left.5 / 1\right)$.

Synthesis of compound 25. A mixture of 7- $\mathrm{Br}(81.6 \mathrm{mg}, 157 \mu \mathrm{mol}), \mathbf{2 4}(85.6 \mathrm{mg}$, $105 \mu \mathrm{mol})$ and $\mathrm{K}_{2} \mathrm{CO}_{3}(72.6 \mathrm{mg}, 525 \mu \mathrm{mol})$ in $\mathrm{MeCN}(1.0 \mathrm{ml})$ was stirred for $2 \mathrm{~h}$ at $60^{\circ} \mathrm{C}$. After the addition of $\mathrm{Et}_{2} \mathrm{O}(5.0 \mathrm{ml})$ and $1 \mathrm{M}$ hydrochloric acid $(5.0 \mathrm{ml})$, the aq mixture was extracted with $\mathrm{Et}_{2} \mathrm{O}$. The organic layer was successively washed with satd aq $\mathrm{NaHCO}_{3}$ and brine. After the general drying procedure, the crude product was purified by $\mathrm{CC}\left(8.0 \mathrm{~g}\right.$ of $\mathrm{SiO}_{2}, n$-hexane/EtOAc $=10 / 1$ to $\left.3 / 1\right)$ to afford 25 (121 $\mathrm{mg}, 92 \%$ yield) as a red syrup.

Synthesis of compound 26. A mixture of 25 ( $244 \mathrm{mg}, 194 \mu \mathrm{mol}), \mathrm{Et}_{3} \mathrm{SiH}$ $(33.8 \mathrm{mg}, 291 \mu \mathrm{mol})$ and $\mathrm{Pd}\left(\mathrm{PPh}_{3}\right)_{4}(22.4 \mathrm{mg}, 19.4 \mu \mathrm{mol})$ in $\mathrm{DMF}(2.0 \mathrm{ml})$ was stirred for 10 min at $80^{\circ} \mathrm{C}$. After the addition of $\mathrm{Et}_{2} \mathrm{O}(3.0 \mathrm{ml})$ and $\mathrm{H}_{2} \mathrm{O}(3.0 \mathrm{ml})$, the aq mixture was extracted with $\mathrm{Et}_{2} \mathrm{O}$. The organic layer was successively washed with satd aq $\mathrm{NaHCO}_{3}$ and brine. After the general drying procedure, the crude product was purified by $\mathrm{CC}\left(8.0 \mathrm{~g}\right.$ of $\mathrm{SiO}_{2}, n$-hexane/EtOAc $=10 / 1$ to 3/1) to afford 26 (168 $\mathrm{mg}, 75 \%$ yield) as a colourless syrup.

Synthesis of compound 32. A mixture of 7- $\mathrm{Br}(268 \mathrm{mg}, 516 \mu \mathrm{mol}), 31(83.0 \mathrm{mg}$, $129 \mu \mathrm{mol})$ and $\mathrm{K}_{2} \mathrm{CO}_{3}(89.1 \mathrm{mg}, 645 \mu \mathrm{mol})$ in DMSO $(1.3 \mathrm{ml})$ was stirred for $15 \mathrm{~min}$ at $70^{\circ} \mathrm{C}$. After the addition of $\mathrm{Et}_{2} \mathrm{O}(5 \mathrm{ml})$ and $1 \mathrm{M}$ hydrochloric acid $(5 \mathrm{ml})$, the aq mixture was extracted with $\mathrm{Et}_{2} \mathrm{O}$. The organic layer was successively washed with satd aq $\mathrm{NaHCO}_{3}$ and brine. After the general drying procedure, the resulting residue was purified by CC ( $2.5 \mathrm{~g}_{\text {of }} \mathrm{SiO}_{2}, n$-hexane/toluene/ $\mathrm{Et}_{2} \mathrm{O}=5 / 3 / 2$ to $\left.2 / 3 / 2\right)$ to afford 32 ( $131 \mathrm{mg}, 94 \%$ yield) as a red syrup.

Synthesis of compound 33. A mixture of $32(80.5 \mathrm{mg}, 74.3 \mu \mathrm{mol}), \mathrm{Et}_{3} \mathrm{SiH}$ $(13.0 \mathrm{mg}, 111 \mu \mathrm{mol})$ and $\mathrm{Pd}\left(\mathrm{PPh}_{3}\right)_{4}(8.6 \mathrm{mg}, 7.4 \mu \mathrm{mol})$ in $\mathrm{DMF}(6.0 \mathrm{ml})$ was stirred for $10 \mathrm{~min}$ at $80^{\circ} \mathrm{C}$. After the addition of $\mathrm{Et}_{2} \mathrm{O}(3 \mathrm{ml})$ and $1 \mathrm{M}$ hydrochloric acid $(3 \mathrm{ml})$, the aq mixture was extracted with $\mathrm{Et}_{2} \mathrm{O}$. The organic layer was successively washed with satd aq $\mathrm{NaHCO}_{3}$ and brine. After the general drying procedure, the resulting residue was purified by $\mathrm{CC}\left(2.5 \mathrm{~g}\right.$ of $\mathrm{SiO}_{2}, n$-hexane/toluene/ $\mathrm{EtOAc}=5 / 3 / 1$ to $2 / 3 / 2)$ to afford $33(60.1 \mathrm{mg}, 83 \%$ yield $)$ as a colourless syrup.

Synthesis of compound 36. A mixture of 3,4,5-tri-O-benzylgallic acid ${ }^{64}(821 \mathrm{mg}$, $1.86 \mathrm{mmol})$, oxalyl chloride $(360 \mathrm{mg}, 2.84 \mathrm{mmol})$ and DMF $(0.1 \mathrm{ml})$ in toluene $(10 \mathrm{ml})$ was stirred for $45 \mathrm{~min}$ at $70^{\circ} \mathrm{C}$. The reaction mixture was concentrated, and toluene $(10 \mathrm{ml})$ was added to the residue. The desired acid chloride dissolved into toluene, whereas a yellow and highly viscous side-product remained undissolved. Thus, the toluene solution was decanted into another flask, and the former flask was rinsed with toluene $(5 \mathrm{ml})$. The combined toluene solution was concentrated to afford 3,4,5-tri-O-benzylgallic acid chloride as a yellow syrup. Without purification, the crude product was used in the next reaction.

To a solution of 35 (ref. 58) (100 mg, $373 \mu \mathrm{mol}$ ) and ${ }^{i} \mathrm{Pr}_{2} \mathrm{NEt}(1.5 \mathrm{ml})$ in $\mathrm{CH}_{2} \mathrm{Cl}_{2}$ $(10 \mathrm{ml})$ was added a solution of the acid chloride in $\mathrm{CH}_{2} \mathrm{Cl}_{2}(10 \mathrm{ml})$. After the mixture was stirred for $25 \mathrm{~h}$ at RT, 4-(dimethylamino)pyridine $(2.1 \mathrm{mg}, 17.2 \mu \mathrm{mol})$ was added. The mixture was stirred for $24 \mathrm{~h}$ at reflux. After the addition of $\mathrm{MeOH}$ $(5 \mathrm{ml})$ and $\mathrm{H}_{2} \mathrm{O}(10 \mathrm{ml})$, the aq mixture was extracted with EtOAc. The organic layer was successively washed with $\mathrm{H}_{2} \mathrm{O}$ and brine. After the general drying procedure, a mixture of desired trigallate and 3,4,5-tri-O-benzylgallic anhydride was obtained through crystallization (benzene/ $n$-hexane), which was used for the next transformation.

To a solution of the product $(672 \mathrm{mg})$ in THF $(8.0 \mathrm{ml})$ was added a mixture of ${ }^{i} \mathrm{PrOH}$ and conc. hydrochloric acid $(\mathrm{v} / \mathrm{v}=50 / 1,4.0 \mathrm{ml})$. After being stirred for $22 \mathrm{~h}$ at $55^{\circ} \mathrm{C}$, the mixture was concentrated to remove the ${ }^{i} \mathrm{PrOH}$ and THF. The remaining aq mixture was extracted with $\mathrm{Et}_{2} \mathrm{O}$. The organic layer was successively washed with satd aq $\mathrm{NaHCO}_{3}$ and brine. After the general drying procedure, the resulting residue was purified by $\mathrm{CC}\left(30 \mathrm{~g}\right.$ of $\mathrm{SiO}_{2}, n$-hexane/EtOAc $=2 / 1$ to $\left.1 / 1.5\right)$ to afford $36(416 \mathrm{mg}, 78 \%$ yield from $\mathbf{3 5})$ as a colourless amorphous solid.
Synthesis of compound 38. A mixture of $\mathbf{3 6}(350 \mathrm{mg}, 241 \mu \mathrm{mol}), 37(228 \mathrm{mg}$, $290 \mu \mathrm{mol}), 4$-(dimethylamino)pyridine $(36 \mathrm{mg}, 290 \mu \mathrm{mol})$ and $\mathrm{N}$-(3-dimethylaminopropyl)- $N$ '-ethylcarbodiimide $\cdot \mathrm{HCl}(111 \mathrm{mg}, 578 \mu \mathrm{mol})$ in $\mathrm{CH}_{2} \mathrm{Cl}_{2}(24 \mathrm{ml})$ was stirred for $3 \mathrm{~h}$ at $0^{\circ} \mathrm{C}$ followed by for $18 \mathrm{~h}$ at RT. After the addition of EtOAc $(20 \mathrm{ml})$ and $1 \mathrm{M}$ hydrochloric acid $(20 \mathrm{ml})$, the aq mixture was extracted with EtOAc. The organic layer was successively washed with $\mathrm{H}_{2} \mathrm{O}$ and brine. After the general drying procedure, the crude product was purified by CC $\left(15 \mathrm{~g} \mathrm{of} \mathrm{SiO}_{2}\right.$, $n$-hexane/EtOAc $=5 / 1$ to $2 / 1$ ) to afford 38 (393 mg, $74 \%$ yield) as a colourless amorphous solid.

Synthesis of compound 39. To a solution of $38(163 \mathrm{mg}, 74.1 \mu \mathrm{mol})$ in THF $(3.0 \mathrm{ml})$ was added a mixture of ${ }^{i} \mathrm{PrOH}$ and conc. hydrochloric acid $(\mathrm{v} / \mathrm{v}=50 / 1$, $1.0 \mathrm{ml}$ ). The mixture was stirred for $26 \mathrm{~h}$ at $55^{\circ} \mathrm{C}$. After the addition of satd aq $\mathrm{NaHCO}_{3}(10 \mathrm{ml})$, the mixture was extracted with $\mathrm{Et}_{2} \mathrm{O}$. The organic layer was successively washed with $\mathrm{H}_{2} \mathrm{O}$ and brine. After the general drying procedure, the crude product was purified by CC $\left(5 \mathrm{~g}\right.$ of $\mathrm{SiO}_{2}, n$-hexane/EtOAc $=5 / 1$ to $\left.2 / 1\right)$ to afford 39 (144 $\mathrm{mg}, 92 \%)$ as a colourless syrup.

Synthesis of compound 40. A mixture of $39(454 \mathrm{mg}, 215 \mu \mathrm{mol}), \mathrm{K}_{2} \mathrm{CO}_{3}(323 \mathrm{mg}$, $2.34 \mathrm{mmol})$ and $\mathrm{BnBr}(36.8 \mathrm{mg}, 215 \mu \mathrm{mol})$ in DMF $(2.5 \mathrm{ml})$ was stirred for $5.5 \mathrm{~h}$ at RT. After the addition of $\mathrm{Et}_{2} \mathrm{O}(5.0 \mathrm{ml})$ and $1 \mathrm{M}$ hydrochloric acid $(5.0 \mathrm{ml})$, the aq mixture was extracted with $\mathrm{Et}_{2} \mathrm{O}$. The organic layer was successively washed with satd aq $\mathrm{NaHCO}_{3}$ and brine. After the general drying procedure, the crude product was purified by CC $\left(50 \mathrm{~g}\right.$ of $\mathrm{SiO}_{2}, n$-hexane/toluene/EtOAc $=20 / 5 / 2$ to $\left.5 / 5 / 2\right)$ to afford 40 (76.8 $\mathrm{mg}, 20 \%$ yield) as a colourless syrup, $41(71.4 \mathrm{mg}, 19 \%)$ as a colourless syrup, full-Bn tellimagrandin II (42) $(83.0 \mathrm{mg}, 21 \%)$ as a colourless amorphous solid, and recovered 39 (132 mg, 38\%). The ${ }^{1} \mathrm{H}$ NMR data of $\mathbf{4 2}$ were identical to those previously reported ${ }^{60}$.

Synthesis of compound 43. A mixture of $\mathbf{4 0}(15.6 \mathrm{mg}, 7.09 \mu \mathrm{mol}),{ }^{i} \mathrm{Pr}_{2} \mathrm{NEt}$ $(2.3 \mathrm{mg}, 18 \mu \mathrm{mol})$ and $\mathrm{MOMCl}(0.9 \mathrm{mg}, 10 \mu \mathrm{mol})$ in $\mathrm{CH}_{2} \mathrm{Cl}_{2}(0.5 \mathrm{ml})$ was stirred for $1 \mathrm{~h}$ at $\mathrm{RT}$. After the addition of $\mathrm{Et}_{2} \mathrm{O}(5 \mathrm{ml})$ and $1 \mathrm{M}$ hydrochloric acid $(3 \mathrm{ml})$, the aq mixture was extracted with $\mathrm{Et}_{2} \mathrm{O}$. The organic layer was successively washed with $\mathrm{H}_{2} \mathrm{O}$ and brine. After the general drying procedure, the crude product was purified by $\mathrm{CC}\left(1.0 \mathrm{~g}\right.$ of $\mathrm{SiO}_{2}, n$-hexane/EtOAc $=5 / 1$ to $\left.2 / 1\right)$ to afford $43(15.5 \mathrm{mg}$, $97 \%$ yield) as a colourless syrup.

Synthesis of compound 44. A solution of $7-\mathrm{Br}(88.8 \mathrm{mg}, 171 \mu \mathrm{mol}), 40(188 \mathrm{mg}$, $85.4 \mu \mathrm{mol})$ and $\mathrm{K}_{2} \mathrm{CO}_{3}(59.0 \mathrm{mg}, 427 \mu \mathrm{mol})$ in $\mathrm{MeCN}(1.0 \mathrm{ml})$ was stirred for $2 \mathrm{~h}$ at $60^{\circ} \mathrm{C}$. After the addition of $\mathrm{Et}_{2} \mathrm{O}(5.0 \mathrm{ml})$ and $1 \mathrm{M}$ hydrochloric acid $(5.0 \mathrm{ml})$, the aq mixture was extracted with $\mathrm{Et}_{2} \mathrm{O}$. The organic layer was successively washed with satd aq $\mathrm{NaHCO}_{3}$ and brine. After the general drying procedure, the crude product was purified by CC $\left(6.0 \mathrm{~g}\right.$ of $\mathrm{SiO}_{2}, n$-hexane/EtOAc $=10 / 1$ to $\left.2 / 1\right)$ to afford $4 \mathbf{4}(218 \mathrm{mg}, 97 \%$ yield $)$ as a red syrup.

Synthesis of compound 45. A mixture of $44(332 \mathrm{mg}, 126 \mu \mathrm{mol}), \mathrm{Et}_{3} \mathrm{SiH}$ $(22.0 \mathrm{mg}, 189 \mu \mathrm{mol})$ and $\mathrm{Pd}\left(\mathrm{PPh}_{3}\right)_{4}(14.6 \mathrm{mg}, 12.6 \mu \mathrm{mol})$ in DMF $(1.5 \mathrm{ml})$ was stirred for $10 \mathrm{~min}$ at $80^{\circ} \mathrm{C}$. After the addition of $\mathrm{Et}_{2} \mathrm{O}(3.0 \mathrm{ml})$ and $\mathrm{H}_{2} \mathrm{O}(3.0 \mathrm{ml})$, the aq mixture was extracted with $\mathrm{Et}_{2} \mathrm{O}$. The organic layer was successively washed with satd aq $\mathrm{NaHCO}_{3}$ and brine. After the general drying procedure, the crude product was purified by $\mathrm{CC}\left(10 \mathrm{~g}\right.$ of $\mathrm{SiO}_{2}, n$-hexane/toluene/EtOAc $=30 / 5 / 2$ to $8 / 5 / 2)$ to afford 45 (306 $\mathrm{mg}$, 95\% yield) as a pale yellow syrup.

Synthesis of compound 46. A mixture of 45 (306 mg, $102 \mu \mathrm{mol}$ ), $\mathrm{K}_{2} \mathrm{CO}_{3}$ $(70.5 \mathrm{mg}, 510 \mu \mathrm{mol})$ and $\mathrm{BnBr}(26.2 \mathrm{mg}, 153 \mu \mathrm{mol})$ in $\mathrm{MeCN}(1.5 \mathrm{ml})$ was stirred for $8.5 \mathrm{~h}$ at RT. After the addition of $\mathrm{Et}_{2} \mathrm{O}(5.0 \mathrm{ml})$ and $1 \mathrm{M}$ hydrochloric acid $(5.0 \mathrm{ml})$, the aq mixture was extracted with $\mathrm{Et}_{2} \mathrm{O}$. The organic layer was successively washed with satd aq $\mathrm{NaHCO}_{3}$ and brine. After the general drying procedure, the crude product was purified by $\mathrm{CC}\left(15 \mathrm{~g}\right.$ of $\mathrm{SiO}_{2}, n$-hexane/toluene/EtOAc $=$ $30 / 5 / 2$ to $12 / 5 / 2)$ to afford 46 (230.8 $\mathrm{mg}, 86 \%$ yield) as a colourless syrup.

Synthesis of compound 47. To a stirred solution of $46(238 \mathrm{mg}, 88.0 \mu \mathrm{mol})$, 2-methyl-2-butene $(0.1 \mathrm{ml})$ and $\mathrm{NaH}_{2} \mathrm{PO}_{4}(20.6 \mathrm{mg}, 132 \mu \mathrm{mol})$ in $\mathrm{THF} /{ }^{t} \mathrm{BuOH}$ $(\mathrm{v} / \mathrm{v}=1 / 1,2.0 \mathrm{ml})$ was added a solution of $\mathrm{NaClO}_{2}(11.9 \mathrm{mg}, 132 \mu \mathrm{mol})$ in $\mathrm{H}_{2} \mathrm{O}$ $(0.5 \mathrm{ml})$. The reaction mixture was stirred at RT for $30 \mathrm{~min}$ under air. After the addition of $\mathrm{H}_{2} \mathrm{O}(5.0 \mathrm{ml})$, the aq mixture was extracted with $\mathrm{Et}_{2} \mathrm{O}$. The organic layer was successively washed with satd aq $\mathrm{NaHCO}_{3}$ and brine. After the general drying procedure, the resulting residue was purified by $\mathrm{CC}\left(5.0 \mathrm{~g}^{\circ} \mathrm{SiO}_{2}, n\right.$-hexane/ toluene/EtOAc $=10 / 5 / 2$ to $5 / 0 / 1$ to $1 / 0 / 1)$ to afford $\mathbf{4 7}(179 \mathrm{mg}, 77 \%$ yield) as a pale yellow syrup.

Synthesis of compound 2. A mixture of $47(22.5 \mathrm{mg}, 8.53 \mu \mathrm{mol})$ and $\mathrm{Pd}$ on carbon $(10 \mathrm{wt} . \%, 5.0 \mathrm{mg})$ in acetone $(1.0 \mathrm{ml})$ was stirred for $5.5 \mathrm{~h}$ at RT under a $\mathrm{H}_{2}$ atmosphere. The mixture was filtered through a cotton-Celite pad to remove the catalyst and carbon. The crude product was dissolved in $1 \mathrm{M}$ hydrochloric acid and purified by CC ( $500 \mathrm{mg}$ of Sephadex LH-20, $\mathrm{H}_{2} \mathrm{O}$ to $\left.\mathrm{MeOH}\right)$ to afford $2(9.2 \mathrm{mg}$, 
97\% yield) as a pale yellow syrup. ${ }^{1} \mathrm{H}$ NMR, ${ }^{13} \mathrm{C}$ NMR, HRMS and optical rotation data for $\mathbf{2}$ were in agreement with those previously reported ${ }^{57}$.

Synthesis of compound 48. A mixture of synthesized $2(5.5 \mathrm{mg}, 4.97 \mu \mathrm{mol})$, $\mathrm{K}_{2} \mathrm{CO}_{3}(65.0 \mathrm{mg}, 470 \mu \mathrm{mol})$ and MeI $(228 \mathrm{mg}, 1.61 \mu \mathrm{mol})$ in DMF $(0.25 \mathrm{ml})$ was stirred for $10 \mathrm{~min}$ at RT. After the addition of $1 \mathrm{M}$ hydrochloric acid $(3.0 \mathrm{ml})$, the aq mixture was extracted with $\mathrm{Et}_{2} \mathrm{O}$. The organic layer was successively washed with satd aq $\mathrm{NaHCO}_{3}$ and brine. After the general drying procedure, the resulting residue was purified by CC $\left(500 \mathrm{mg}\right.$ of $\mathrm{SiO}_{2}, n$-hexane/EtOAc $=5 / 1$ to $\left.1 / 2\right)$ to afford $48\left(3.6 \mathrm{mg}, 53 \%\right.$ yield) as a pale yellow syrup. ${ }^{1} \mathrm{H}$ NMR and optical rotation data for $\mathbf{4 8}$ were identical to those previously reported ${ }^{57}$.

\section{References}

1. Snyder, S. A., ElSohly, A. M. \& Kontes, F. Synthetic approaches to oligomeric natural products. Nat. Prod. Rep. 28, 897-924 (2011).

2. Quideau, S., Deffieux, D., Douat-Casassus, C. \& Pouységu, L. Plant polyphenols: chemical properties, biological activities, and synthesis. Angew. Chem. Int. Ed. 50, 586-621 (2011).

3. Ohmori, K., Shono, T., Hatakoshi, Y., Yano, T. \& Suzuki, K. Integrated synthetic strategy for higher catechin oligomers. Angew. Chem. Int. Ed. 50, 4862-4867 (2011)

4. Snyder, S. A., Gollner, A. \& Chiriac, M. Regioselective reactions for programmable resveratrol oligomer synthesis. Nature 474, 461-466 (2011).

5. Ascacio-Valdés, J. A. et al. Ellagitannins: biosynthesis, biodegradation and biological properties. J. Med. Plants Res. 5, 4696-4703 (2011).

6. Quideau, S. Chemistry and Biology of Ellagitannins: an Underestimated Class of Bioactive Plant Polyphenols (World Scientific, 2009).

7. Pouységu, L., Deffieux, D., Malik, G., Natangelo, A. \& Quideau, S. Synthesis of Ellagitannin Natural Products. Nat. Prod. Rep. 28, 853-874 (2011).

8. Latté, K. P. \& Kolodziej, H. Pelargoniins, New Ellagitannins from Pelargonium reniforme. Phytochemistry 54, 701-708 (2000).

9. Yoshida, T., Itoh, H., Matsunaga, S., Tanaka, R. \& Okuda, T. Tannins and related polyphenols of euphorbiaceous plants. IX. Hydrolyzable tannins with ${ }^{1} \mathrm{C}_{4}$ glucose core from Phyllanthus flexuosus MUELL. ARG. Chem. Pharm. Bull. 40, 53-60 (1992).

10. Gross, G. G., Hemingway, R. W. \& Yoshida, T. Plant Polyphenol 2. Chemistry, Biology, Pharmacology and Ecology (Kluwer Academic/Pleum Publishers, 1999).

11. Chassaing, S. et al. Physicochemical studies of new Anthocyano-Ellagitannin hybrid pigments: about the origin of the influence of Oak C-glycosidic ellagitannins on wine. Eur. J. Org. Chem. 55-63 (2010).

12. Ito, H. et al. Cowaniin, a $C$-glucosidic ellagitannin dimer linked through catechin from Cowania Mexicana. Chem. Pharm. Bull. 55, 492-494 (2007).

13. Quideau, S. et al. DNA topoisomerase inhibitor acutissimin A and other flavano-ellagitannins in red wine. Angew. Chem. Int. Ed. 42, 6012-6014 (2003).

14. Li, H., Tanaka, T., Zhang, Y.-J., Yang, C.-R. \& Kouno, I. Rubusuaviins A-F, monomeric and oligomeric ellagitannins from Chinese sweet tea and their $\alpha$-amylase inhibitory activity. Chem. Pharm. Bull. 55, 1325-1331 (2007).

15. Feldman, K. S. \& Ensel, S. M. Ellagitannin chemistry. Preparative and mechanistic studies of the biomimetic oxidative coupling of galloyl esters. J. Am. Chem. Soc. 116, 3357-3366 (1994).

16. Khanbabaee, K. \& van Ree, T. Strategies for the synthesis of ellagitannins. Synthesis 1585-1610 (2001)

17. Su, X., Surry, D. S., Spandl, R. J. \& Spring, D. R. Total synthesis of sanguiin H-5. Org. Lett. 10, 2593-2596 (2008).

18. Yamada, H., Nagao, K., Dokei, K., Kasai, Y. \& Michihata, N. Total synthesis of (-)-Corilagin. J. Am. Chem. Soc. 130, 7566-7567 (2008).

19. Feldman, K. S. Recent progress in ellagitannin chemistry. Phytochemistry 66, 1984-2000 (2005)

20. Feldman, K. S., Lawlor, M. D. \& Sahasrabudhe, K. Ellagitannin chemistry. evolution of a three-component coupling strategy for the synthesis of the dimeric ellagitannin coriariin A and a dimeric gallotannin analogue. J. Org. Chem. 65, 8011-8019 (2000).

21. Feldman, K. S., Quideau, S. \& Appel, H. M. Galloyl-Derived Orthoquinones as Reactive Partners in Nucleophilic Additions and Diels-Alder Dimerizations: A Novel Route to the Dehydrodigalloyl Linker Unit of Agrimoniin-Type Ellagitannins. J. Org. Chem. 61, 6656-6665 (1996)

22. Truce, W. E., Kreider, E. M. \& Brand, W. W. Organic Reactions Vol. 18, 99-215 (John Wiley \& Sons, Inc. 1970)

23. Lin, J.-H., Ishimatsu, M., Tanaka, T., Nonaka, G. \& Nishioka, I. Tannins and related compounds. xcvi. structures of macaranins and macarinins, new hydrolyzable tannins possessing macaranoyl and tergalloyl ester groups, from the leaves of Macaranga sinensis (baill.) muell.-arg. Chem. Pharm. Bull. 38, 1844-1851 (1990).

24. Abe, H., Sahara, Y., Matsuzaki, Y., Takeuchi, Y. \& Harayama, T. Enantioselective synthesis of valoneic acid derivative. Tetrahedron Lett. 49, 605-609 (2008)
25. Shioe, K. et al. Syntheses of All-methylated ellagitannin, isorugosin B and rugosin B. Tetrahedron 67, 1960-1970 (2011).

26. Lipshutz, B. H., Liu, Z.-P. \& Kayser, F. Cyanocuprate-mediated intramolecular blaryl couplings applied to an ellagitannin. Synthesis of $(+)-\mathrm{O}-$ permethyltellimagrandln II. Tetrahedron Lett. 35, 5567-5570 (1994).

27. Nelson, T. D. \& Meyers, A. I. A rapid total synthesis of an ellagitannin. J. Org. Chem. 59, 2577-2580 (1994).

28. Yamada, H. et al. The first construction of a 3,6-Bridged ellagitannin skeleton with ${ }^{1} \mathrm{C}_{4} / \mathrm{B}$ glucose core; synthesis of nonamethylcorilagin. Tetrahedron Lett. 45, 487-489 (2004).

29. Quideau, S. \& Feldman, K. S. Ellagitannin Chemistry. Chem. Rev. 96, 475-503 (1996).

30. Bestson, M. S., Clayden, J., Worrall, C. P. \& Peace, S. Three Groups good, four groups bad? Atropisomerism in ortho-substituted diaryl ethers. Angew. Chem. Int. Ed. 45, 5803-5807 (2006).

31. Olivera, R., SanMartin, R., Churruca, F. \& Domíngues, E. Revisiting the Ullmann-ether reaction: a concise and amenable synthesis of novel dibenzoxepino $[4,5-d]$ pyrazoles by intramolecular etheration of 4,5-(o,o'-halohydroxy)arylpyrazoles. J. Org. Chem. 67, 7215-7225 (2002).

32. Domon, L. \& Uguen, D. Toward a total synthesis of stigmatellin; obtention of an advanced fragment from gallic acid. Tetrahedron. Lett. 41, 5501-5505 (2000).

33. Pearson, A. J. \& Bruhn, P. R. Studies on the synthesis of aryl ethers using arene-manganese chemistry. J. Org. Chem. 56, 7092-7097 (1991).

34. Liao, C.-C. \& Peddinti, R. K. Masked o-benzoquinones in organic synthesis. Acc. Chem. Res. 35, 856-856 (2002).

35. Becker, H.-D., Bremholt, T. \& Alder, E. Oxidative formation and photochemical isomerization of spiro-epoxy-2,4-cyclohexadienones. Tetrahedron Lett. 41, 4205-4208 (1972).

36. Anderson, G. \& Berntsson, P. Periodate oxidation of phenols. XVIII. Oxidation of 2-methoxy-phenols with periodic acid in methanol. Acta. Chem. Scand B 29, 948-952 (1975)

37. Lai, C.-H., Shen, Y.-L. \& Liao, C.-C. Synthesis of stable bromo-substituted masked o-benzoquinones and their application to the synthesis of bicyclo[2.2.2]octenones. Synlett. 1351-1352 (1997).

38. Deffieux, D., Fabre, I., Titz, A., Léger, J.-M. \& Quideau, S. Electrochemical synthesis of dimerizing and nondimerizing orthoquinone monoketals. J. Org. Chem. 69, 8731-8738 (2004).

39. Nishimura, T., Onoue, T., Ohe, K. \& Uemura, S. Palladium(II)-catalyzed oxidation of alcohols to aldehydes and ketones by molecular oxygen. J. Org. Chem. 64, 6750-6755 (1999).

40. Kametler, L. et al. Synthese von plagiochin A und B, zwei macrocyclische Bis(bibenzylether) aus Plagiochila acantophylla. Liebigs Ann. Chem. 1239-1243 (1992).

41. Li, C. et al. A novel and efficient oxidation of benzyl alcohols to benzaldehydes with DMSO catalyzed by acids. Synlett. 2014-2042 (2002).

42. Tang, J., Zhu, J., Shen, Z. \& Zhang, Y. Efficient and convenient oxidation of organic halides to carbonyl compounds by $\mathrm{H}_{2} \mathrm{O}_{2}$ in ethanol. Tetrahedron. Lett. 48, 1919-1921 (2007).

43. Aggarwal, R., Giles, R. G. F., Green, I. R., Oosthuizen, F. J. \& Taylor, P. Syntheses in enantiopure form of four diastereoisomeric naphthopyranquinones derived from aphid insect pigments. Org. Biomol. Chem. 3, 263-273 (2005).

44. Alam, A., Takaguchi, Y., Ito, H., Yoshida, T. \& Tsuboi, S. Multi-functionalization of gallic acid towards improved synthesis of $\alpha$ - and $\beta$-DDB. Tetrahedron 61, 1909-1918 (2005)

45. Quideau, S., Looney, M., Pouységu, L., Ham, S. \& Birney, D. M. Orthoquinone monoketal chemistry. experimental and density functional theory studies on orthoquinol acetate rearrangements. Tetrahedron Lett. 40, 615-618 (1999).

46. Gu, Z. \& Zakarian, A. Studies toward the synthesis of Maoecrystal V. Org. Lett. 13, 1080-1082 (2011).

47. Sundararaju, B., Achard, M. \& Bruneau, C. Transition metal catalyzed nucleophilic allylic substitution: activation of allylic alcohols via $\pi$-allylic species. Chem. Soc. Rev. 41, 4467-4483 (2012).

48. Guivé, F. Allylic protecting groups and their use in a complex environment part ii: allylic protecting groups and their removal through catalytic palladium $\pi$-allyl methodology. Tetrahedron 54, 2967-3042 (1998).

49. Takemura, A. et al. Synthesis of the EF-ring segment of ciguatoxin CTX1B based on novel regioselective reduction of unsaturated cyanohydrins and ringclosing olefin metathesis. Tetrahedron 61, 7392-7419 (2005).

50. Dolson, M. G., Jackson, D. K. \& Swenton, J. S. Anodic oxidation as a general route to benzoquinone bis- and mono-acetals. J. Chem. Soc. Chem. Comm. 327-329 (1979).

51. Mascall, K. C. \& Jacobi, P. A. Furanosteroid studies. Improved synthesis of the A,B,C,E-ring core of Viridin. Tetrahedron Lett. 53, 1620-1623 (2012).

52. Arasappan, A. \& Fraser-Reid, B. $n$-Pentenyl glycoside methodology in the stereoselective construction of the tetrasaccharyl cap portion of Leishmania lipophosphoglycan. J. Org. Chem. 61, 2401-2406 (1996). 
53. Asakura, N. et al. Synthesis of Chiral and modifiable hexahydroxydiphenoyl compounds. J. Org. Chem. 76, 9711-9719 (2011).

54. Xia, J. et al. Use of 1,2-dichloro 4,5-dicyanoquinone (DDQ) for cleavage of the 2-naphthylmethyl (NAP) group. Tetrahedron Lett. 41, 169-173 (2000).

55. Ishimaru, K. et al. Tannins and related compounds LXXII. Isolation and characterization of mongolicanin (procyanidinoellagitannin), mongolinin A, acutissimin $\mathrm{C}$ and vescalagin carboxoylic acid, novel tannins from Quercus mongolica var grosseserrata. Chem. Pharm. Bull. 36, 3319-3327 (1988).

56. Yoshida, T. et al. Structures of alnusiin and bicornin, new hydrolyzable tannins having a monolactonized tergalloyl group. Chem. Pharm. Bull. 10, 2655-2660 (1989).

57. Hatano, T., Ogawa, N., Yasuhara, T. \& Okuda, T. Tannins of rosaceous plants. VIII. hydrolyzable tannin monomers having a valoneoyl group from flower petals of Rosa rugosa THUNB. Chem. Pharm. Bull. 38, 3308-3313 (1990).

58. Drew, K. N. \& Gross, P. H. C-glycoside syntheses II: henry condensations of 4,6-O-alkylidene pyranoses with a 1,3-proton transfer catalyst-A route to blocked aminomethyl-C-glydosides. Tetrahedron 47, 6113-6126 (1991).

59. Yamaguchi, S. et al. Roxbin B is cuspinin: structural revision and total synthesis. J. Org. Chem. 78, 5410-5417 (2013).

60. Feldman, K. S. \& Sahasrabudhe, K. Ellagitannin chemistry. Syntheses of tellimagrandin II and a dehydrodigalloyl ether-containing dimeric gallotannin analogue of coriariin A. J. Org. Chem. 64, 209-216 (1999).

61. Lindgren, B. O. \& Nilsson, T. Preparation of carboxylic acid from aldehydes (including hydroxylated benzaldehydes) by oxidation with chlorite. Acta Chem. Scand. 27, 888-890 (1973).

62. Kraus, G. A. \& Roth, B. Synthetic studies toward Verrucarol. 2. Synthesis of the AB ring system. J. Org. Chem. 45, 4825-4830 (1980).

63. Bal, B. S., Childers, W. E. \& Pinnick, H. W. Oxidation of $\alpha, \beta$-unsaturated aldehides. Tetrahedron 37, 2091-2096 (1981).
64. Kasai, Y., Michihata, N., Nishimura, H., Hirokane, T. \& Yamada, H. Total synthesis of (+)-davidiin. Angew. Chem. Int. Ed. 51, 8026-8029 (2012).

\section{Acknowledgements}

We thank Professor Dr Tsutomu Hatano (Okayama University, Japan) for the identification of natural rugosin A. We thank Osaka Synthetic Chemical Laboratories, Inc. for provision of $N$-(3-dimethylaminopropyl)- $N^{\prime}$-ethylcarbodiimide $\cdot \mathrm{HCl}$. The MEXT-Supported Program for the Strategic Research Foundation at Private Universities (S1311046) partly supported this work.

\section{Author contributions}

T.H. and H.Y. conceived and designed the experiments; T.H. performed all experiments and analysed the data; Y.H., T.I. and K.N. performed experiments, partially analysed the data and confirmed reproducibility; T.H. and H.Y. co-wrote the paper. All authors contributed to the discussions.

\section{Additional information}

Supplementary Information accompanies this paper on http://www.nature.com/ naturecommunications

Competing financial interests: The authors declare no competing financial interests

Reprints and permission information is available online at http://www.npg.nature.com/ reprintsandpermissions/

How to cite this article: Hirokane, T. et al. A unified strategy for the synthesis of highly oxygenated diaryl ethers featured in ellagitannins. Nat. Commun. 5:3478 doi: 10.1038/ ncomms4478 (2014) 